\title{
Habitat heterogeneity and use of physical and acoustic space in anuran communities in Southeastern Brazil
}

\author{
Tiago da Silveira Vasconcelos ${ }^{1,2}$ and Denise de Cerqueira Rossa-Feres ${ }^{3}$ \\ 1 Universidade Estadual Paulista, Programa de Pós-Graduação em Biologia Animal. R. Cristóvão Colombo, 2265, São \\ José do Rio Preto, 15054-000, São Paulo, Brazil. E-mail: zoologia@ig.com.br. \\ 2 Present address: Universidade Estadual Paulista, Programa de Pós-Graduação em Ciências Biológicas - Zoologia. Av. \\ 24A, 1515, Rio Claro, 13506-900, São Paulo, Brazil. \\ 3 Universidade Estadual Paulista, Laboratório de Ecologia Animal, Departamento de Zoologia e Botânica. R. Cristóvão \\ Colombo, 2265, São José do Rio Preto, 15054-000, São Paulo, Brazil. E-mail: denise@ibilce.unesp.br.
}

\begin{abstract}
Habitat heterogeneity and use of physical and acoustic space in anuran communities in Southeastern Brazil. We intended to verify if structural and physiognomical characteristics of water bodies influence on the degree of overlap among calling sites of 23 anurans species, if anuran species use different calling sites in different water bodies, and if there is some relationship between the degree of advertisement call (based on seven call features) and calling site differentiation. Then, we determined calling sites (based in four variables) and recorded the advertisement call for anuran species that occurred in 10 water bodies of northwestern São Paulo State. We also determined the environmental heterogeneity (based in four environmental descriptors) for each water body. Males of most species used similar calling sites in each water body, probably because of the high uniformity of the environment, as a consequence of agricultural impacts on edge vegetation of the studied ponds. Most species (18 out of 19 species) called from different sites in the ponds where they occurred, which can be associated with differences in horizontal and vertical distribution of vegetation in the studied ponds. From the 19 species analyzed, only males of Pseudopaludicola aff. saltica called in sites with the same characteristics in different ponds. Advertisement call of Hylidae species was more similar to each other than were Leiuperidae and Leptodactylidae among themselves. The aquatic/terrestrial anurans (Bufonidae, Leiuperidae, Leptodactylidae and Microhylidae) occupied similar calling sites but presented quite distinct advertisement calls, while Hylidae species presented an inverse pattern: a high similarity on advertisement call features but used different calling sites, which indicates a niche complementarity between physical (calling site use) and acoustic (advertisement call) space use.
\end{abstract}

Keywords: Anura, microspatial distribution, environmental heterogeneity, calling site, advertisement call.

Received 4 June 2008.

Accepted 3 December 2008.

Distributed December 2008. 


\section{Introduction}

In most tropical and subtropical anuran species, breeding is characterized by the aggregation of several species in permanent and temporary ponds during the hot and wet period of the year (Aichinger 1987, Duellman and Trueb 1994). Spatial and temporal overlap of breeding is common (Hofer et al. 2004), thus the potential for inter-specific interactions is high (Duellman and Trueb 1994). Differential use of the acoustic space and calling and oviposition sites are important mechanisms explaining the coexistence of anuran species (Heyer et al. 1990, Rossa-Feres and Jim 2001, Hofer et al. 2004).

Environmental heterogeneity is an important factor determining species richness for different animal groups (e.g. Fraser 1998, Moreno-Rueda and Pizarro 2007), and particularly for amphibians, a large number of breeding microhabitats can increase species richness (Haddad 1998, Haddad and Prado 2005). Although species tend to use the same calling sites in different habitats, intra-specific differences in spatial position of calling males can occur according to the habitat heterogeneity of the ponds (Duellman 1997). Thus, environmental heterogeneity is an important factor determining the number of species occurring in a given pond (Cardoso et al. 1989). A differential use of calling site in anuran assemblages in forested areas (Cardoso et al. 1989, Haddad and Sazima 1992, Bertoluci and Rodrigues 2002) seems to be due to the high environmental heterogeneity, which offers a variety of opportunities for differential use of space during calling activities (Cardoso et al. 1989). In contrast, overlap of calling site in anuran assemblages from open areas is common (Cardoso et al. 1989, Pombal 1997, Rossa-Feres and Jim 2001), and the few opportunities for differential use of space is probably due to low environmental heterogeneity. In such open habitats, differences in the spectral and temporal attributes of male advertisement calls are the main mechanisms of reproductive isolation among species (Hödl 1977, Duellman and Pyles 1983).

These patterns summarized in the last paragraph (species tending to use the same calling site in different habitats, the differential use of calling sites in forested areas and the overlap in open area anuran assemblages) are mainly supported by descriptive studies (Cardoso et al. 1989, Haddad and Sazima 1992, Duellman 1997, Pombal 1997, Bernarde and Anjos 1999, Conte and Machado 2005) whereas no statistical analysis were performed in order to support this statements. Nevertheless, only during the last decade quantitative aspects of anuran calling sites were published (Eterovick and Sazima 2000, Rossa-Feres and Jim 2001, Menin et al. 2005, Santos and Rossa-Feres 2007). These quantitative studies evidenced some exceptions to these patterns, as the differential use of calling sites in open area anuran assemblages (Eterovick and Sazima 2000), and also proposed different approaches concerning the use of advertisement call as a tool assessing how coexisting species use the physical and acoustic space (Martins et al. 2006, Santos and Rossa-Feres 2007). On the other hand, in our concern, no study testing effectively the influence of environmental heterogeneity on patterns of calling site use is available. Thus, in this study we addressed the following questions: 1) is the degree of overlap among anuran species influenced by structural and physiognomical characteristics of water bodies? 2) do conspecifics use different calling sites in different water bodies? 3) is there some relationship between the degree of advertisement call and calling site differentiation?

\section{Material and Methods}

This study was carried out at 10 water bodies (Table 1) located in pasture areas and agricultural cultivations (sugar cane and rubber tree), in the district of Nova Itapirema (21 $04^{\circ} \mathrm{S}$; $49^{\circ} 32^{\prime} \mathrm{W}$ ), municipality of Nova Aliança, in the northwestern region of São Paulo State, 
Table 1 - Main traits of ten water bodies studied in northwestern São Paulo State, Brazil. PP1, Permanent Pond 1; PP2, Permanent Pond 2; PP3, Permanent Pond 3; PP4, Permanent Pond 4; TP1, Temporary Pond 1; TP2, Temporary Pond 2; TS, Temporary Swamp in open area; PS, Permanent Swamp in riparian forest; OS, Open area Streamlet; FS, Riparian Forest Streamlet. AV, Aquatic vegetation (Cyperaceae, Nympheaceae, Pontederiaceae); BG, Bare Ground; TH, "Taboa" (Thyphaceae); EHV, Erect Herbaceous Vegetation (e.g. Asteraceae, Cyperaceae, Malvaceae, Onagraceae, Poaceae, Pteridophyta); SH, Shrubs (e.g. Melastomataceae, Piperaceae, Solanaceae); SHV, Short Herbaceous Vegetation or grasses (Poaceae). The sequences of vegetation types in the items "Interior Vegetation" and "Edge Vegetation" are in decreasing order of predominance.

\begin{tabular}{|c|c|c|c|c|c|c|}
\hline & Geographic coordinates & Duration & $\begin{array}{l}\text { Area } \\
\left(\mathrm{m}^{2}\right)\end{array}$ & $\begin{array}{l}\text { Depth } \\
\text { (m) }\end{array}$ & $\begin{array}{c}\text { Interior } \\
\text { Vegetation }\end{array}$ & Edge Vegetation \\
\hline PP1 & $21^{\circ} 04^{\prime} 41^{\prime \prime} \mathrm{S}, 49^{\circ} 32^{\prime} 20^{\prime \prime} \mathrm{W}$ & Permanent & 580 & 0,7 & $\mathrm{~T}, \mathrm{AV}, \mathrm{EHV}$ & SHV, EHV, SH \\
\hline PP2 & $21^{\circ} 04^{\prime} 33^{\prime \prime} \mathrm{S}, 49^{\circ} 32^{\prime} 21^{\prime \prime} \mathrm{W}$ & Permanent & 300 & 0,7 & $\mathrm{AV}, \mathrm{T}, \mathrm{EHV}$ & SHV, EHV \\
\hline PP3 & $21^{\circ} 04^{\prime} 52^{\prime \prime} \mathrm{S}, 49^{\circ} 31^{\prime} 09^{\prime \prime} \mathrm{W}$ & Permanent & 166,4 & 0,65 & EHV & BG, SHV, EHV, SH \\
\hline PP4 & $21^{\circ} 04^{\prime} 25^{\prime \prime} \mathrm{S}, 49^{\circ} 31^{\prime} 08^{\prime \prime} \mathrm{W}$ & Permanent & 800 & 1,5 & $\mathrm{EHV}$ & SHV, EHV, BG, SH \\
\hline $\mathrm{TP} 1$ & $21^{\circ} 04^{\prime} 40^{\prime \prime} \mathrm{S}, 49^{\circ} 32^{\prime} 23^{\prime \prime} \mathrm{W}$ & Temporary & 704 & 0,7 & AV, EHV & SHV, EHV, SH \\
\hline TP2 & $21^{\circ} 04^{\prime} 44^{\prime \prime} \mathrm{S}, 49^{\circ} 32^{\prime} 20^{\prime \prime} \mathrm{W}$ & Temporary & 32 & 0,4 & $\mathrm{~T}, \mathrm{AV}, \mathrm{EHV}$ & SHV, EHV, SH \\
\hline TS & $21^{\circ} 04^{\prime} 24^{\prime \prime} \mathrm{S}, 49^{\circ} 31^{\prime} 08^{\prime \prime} \mathrm{W}$ & Temporary & 67,5 & 0,4 & $\mathrm{EHV}, \mathrm{AV}$ & SHV, EHV, SH, BG \\
\hline PS & $21^{\circ} 04^{\prime} 28^{\prime \prime} \mathrm{S}, 49^{\circ} 31^{\prime} 14^{\prime \prime} \mathrm{W}$ & Permanent & 58,5 & 0,27 & EHV & EHV, SH, SHV \\
\hline OS & $21^{\circ} 04^{\prime} 43^{\prime \prime} \mathrm{S}, 49^{\circ} 32^{\prime} 21^{\prime \prime} \mathrm{W}$ & Permanent & 1072,5 & 0,5 & - & $\mathrm{EHV}, \mathrm{T}, \mathrm{AV}$ \\
\hline FS & 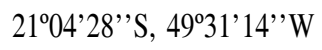 & Permanent & 211,5 & 0,25 & - & SH, EHV, BG \\
\hline
\end{tabular}

Southeastern Brazil. Here the climate is seasonal characterized by a hot and wet season in summer and dry winter (Cwa-Aw of Köppen) (Barcha and Arid 1971). The onset of the rainy season (generally from October to March) varies each year (Rossa-Feres and Jim 2001). Eighty-five percent of the annual rainfall accumulates during the rainy season, with the remaining $15 \%$ falling during the dry season (April to September) (Barcha and Arid 1971). The original vegetation cover of Mesophitic Semideciduous Forest (Atlantic Forest Domain) with patches of Cerrado (Ab'Saber 2003) was intensively deforested for agricultural activities. Consequently, the studied region contains only few and small fragments of original vegetation (São Paulo 2000).

Each pond and stream were visited every two weeks during the rainy seasons of 20012002 (October to March) and 2003-2004
(September to March), and were searched along their perimeters, two or three times each night, between 19:00 and 24:00 h. The calling site of each male was characterized according to Rossa-Feres and Jim (2001) and Santos and Rossa-Feres (2007), in order to represent physic features, spatial position and behavioural characteristics of each male during the calling activity: a) type of substrate (dry soil, moist soil, swampy soil, floating on the water, perched on the vegetation); b) height or depth of calling site (relative to water surface or soil for males that call perched on the vegetation; depth of water column for males floating on the water); c) distance of calling site from the nearest edge, measured from the edge to outside (negative values) or inside (positive values) the pond; and d) orientation of the male in the substrate (males calling from the soil or floating on the water: head towards to the center or to 
the edge of the pond; males calling from vegetation: parallel, vertical or oblique with respect to the water suface).

Niche overlap for calling site (for each one of 10 water bodies) was determined by the application of similarity index of Morisita-Horn (Krebs 1999), and a subsequent cluster analysis (unweighed mean method, UPGMA) was applied in the resultant matrix. In this study a minimum value of $60 \%$ of similarity was considered a cluster. There is no agreed-upon rule in the literature about what minimum value of similarity represents a cluster in a resulting graphic from cluster analysis. However, it is possible to verify how much the resulting graphic represents the original similarity matrix. Therefore, the Cophenetic Correlation Coefficient (r) was calculated to measure the loss of information in the similarity matrix represented by cluster analyses (Romesburg 1984), where $r \geq 0.9$ represents a very good fit, $0.9-0.8$ represents a good fit, $0.8-0.7$ represents a poor fit, and $\mathrm{r}<0.7$ represents a very poor fit (Rohlf 2000). All analyses were performed using NTSYS 2.1 software (Rohlf 2000).

In order to determine the influence of structural and physiognomical characteristics of water bodies on the degree of calling site overlap, four environmental descriptors were determined and ordered in ranks: 1) vegetation height (HEI): $1(0-30 \mathrm{~cm}), 2(31-60 \mathrm{~cm}), 3$ $(61-90 \mathrm{~cm}), 4(91-120 \mathrm{~cm}), 5$ (above 120 $\mathrm{cm})$; 2) percentage of vegetation cover on the water surface (VC): 1 (0-30\%), 2 (31-60\%), and $3(61-100 \%)$; 3 ) size of the water body (SIZ): 1 (up to $67.5 \mathrm{~m}^{2}$ ), 2 (between $67.6 \mathrm{~m}^{2}$ and 255.8 $\mathrm{m}^{2}$ ), 3 (between 255.9 and $704 \mathrm{~m}^{2}$ ) and 4 (over than $705 \mathrm{~m}^{2}$ ); and 4) water body duration (DUR): 1 (temporary; until 5 months), 2 (persistent, between 5 and 12 months), and 3 (permanent). This ordination procedure in ranks was adopted following previous studies analyzing the influence of habitat heterogeneity in open-area anuran assemblages (Vasconcelos and Rossa-Feres 2005, Candeira 2007, Santos et al. 2007), in order to reduce the minor variations of the environmental descriptors evidenced when continuous variables are determined, which can difficult the visualization of a possible pattern.

The influence of structural and physiognomical characteristics of water bodies on the degree of overlap in the calling site was verified by Multiple Linear Regression (F: Zar 1999) between the four environmental descriptors and the percentage of species in each water body with minimum overlap value of $60 \%$ in calling site use (species that overlapped in calling site at least with one species). This analysis was performed separately according to the differential use of space, for those species that called perched on the vegetation (perching guild: Hylidae species, except Pseudis platensis that calls floating on the water) and those that called on the soil or floating on the water (aquatic/terrestrial guild: Bufonidae, Leiuperidae, Leptodactylidae and Microhylidae, which use a two-dimensional space). Spearman correlation $\left(\mathrm{r}_{\mathrm{s}}\right.$, Triola 1999) was applied to determine whether the number of species in ponds influenced the percentage of overlap among perching guild and aquatic/terrestrial guild species, separately. In both regression and correlation analysis, statistical significance was considered when $\mathrm{p}<0.05$.

Intra-specific variation in calling site was investigated for species with $\geq 3$ individuals calling at each water body. Variables (height or depth of calling site and distance from de edge) were compared by analysis of variance (ANOVA): non-normal distribution by KruskalWallis test $(\mathrm{H})$, and Snedecor test $(\mathrm{F})$ for data with normal distributions (Zar 1999, Ayres et al. 2003). Statistical significance was considered when $\mathrm{p}<0.05$.

Advertisement calls were recorded with a portable tape recorder Sony TCM-S64V, onto K-7 tape Sony UX-Pro $60 \mathrm{~min}$, using a portable Sony microphone positioned 1.0 to $1.5 \mathrm{~m}$ from the calling male. Air temperature was recorded with a digital thermohygrometer (Tonka Tec, 
model HT 100). The following call features were determined: note duration (including duration of different notes in calls with more than one type of note); pulse number per note, lower and higher band frequency, lower and higher dominant frequency, and harmonic number. The terminology of call features follows Duellman and Pyles (1983), Duellman and Trueb (1994), and Martins and Jim (2003). Bioacoustics analysis was performed using the software CoolEdit Pro, 2.0 version, with 22000 $\mathrm{Hz}$ sample frequency, option of 256 bands (FFT - Fast Fourier Transform). The Euclidian distance dissimilarity index (Krebs 1999) was calculated to determine the similarity among advertisement calls in the seven measured call features, performed for Hylidae, Leiuperidae and Leptodactylidae species. The Bufonidae and Microhylidae species were not included in this analysis because the low number of species represented in this sampled area (one and two species, respectively). The matrix of dissimilarity was represented by cluster analysis of unweighed mean method (UPGMA) and 60\% of similarity was considered as a cluster. The Cophenetic Correlation Coefficient was also applied to verify how cluster analysis was representative concerning the original matrix of dissimilarity (Rohlf 2000). The relationship between the degree of differentiation of advertisement call and calling site, determined by the dissimilarity and similarity index respectively, was verified comparing of the composition of the clusters evidenced by these analyses.

\section{Results}

We determined 1524 calling sites of males from 23 species (Table 2). The overlap among anuran species was high, because at least $50 \%$ of species was included in the clusters at each one of the water bodies, except the open-area streamlet, where only two species called at different sites (Figures 1 and 2, Table 3). Niche overlap was not correlated with environmental heterogeneity for both guilds analyzed (aquatic/ terrestrial guild: adjusted $\mathrm{r}^{2}=-0.21, \mathrm{~F}_{(4,5)}=0.60$, $\mathrm{p}>0.05$; maximum $\mathrm{t}=0.80$ and minimum $\mathrm{p}=0.42$ for each environmental descriptor; perching guild: adjusted $\mathrm{r}^{2}=-0.46, \mathrm{~F}_{(4,5)}=0.29$, $\mathrm{p}>0.05$; maximum $\mathrm{t}=0.24$ and minimum $\mathrm{p}=$ 0.45 for each environmental descriptor) (Table $3)$. Niche overlap was also not correlated with number of species at each water body (aquatic/ terrestrial guild: $\mathrm{r}_{\mathrm{s}}=0.61, \mathrm{p}=0.08$; perching guild: $\left.r_{\mathrm{S}}=-0,34 ; \mathrm{p}>0.05\right)$.

The calling site overlap was different among guilds of species. Hylidae species were separated in two clusters in five (PP1, PP4, TP1, TP2 and TS) out of seven ponds with four or more species: species that called from high perches and those who called from lower perches. Aquatic/terrestrial species formed only one cluster in five (PP1, PP3, PP4, TP2 and TS) out of this seven ponds (Figures 1 and 2). In the remaining two ponds (PP2 and TP1), aquaticl terrestrial species was separated in two clusters: species that called close to the edge (Figure 1: cluster three at PP2 and TP1) and those that called from the deeper portions inside the ponds (Figure 1: cluster two at PP2 and cluster four at TP1).

The intra-specific variation in calling site was great, because most species (18 out of 19 species) called from different sites in the ponds where they occurred (Table 2). Males of seven species (Hypsiboas albopunctatus, Dendropsophus elianeae, D. nanus, D. sanborni, Leptodactylus podicipinus, Physalaemus cuvieri, and P. marmoratus) called from different heights and different edge distances in different ponds (ANOVA, p < 0.05); the remaining species differed (ANOVA, $\mathrm{p}<0.05$ ) only in one of the variables (depth/height or edge distance) of calling site (Table 2). For most species that called on the vegetation, individuals called from different heights in ponds (ANOVA, p < 0.05), whereas for most species that called on the soil or floating on the water, individuals chose calling sites at different distances from the water's edge in 

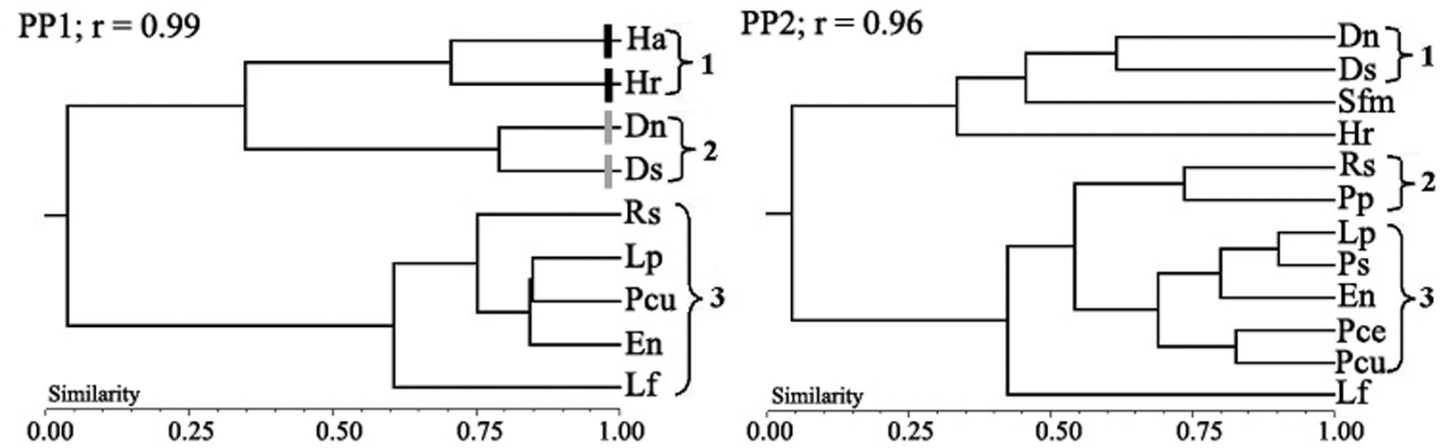

$\mathrm{PP} 3 ; \mathrm{r}=0.94$

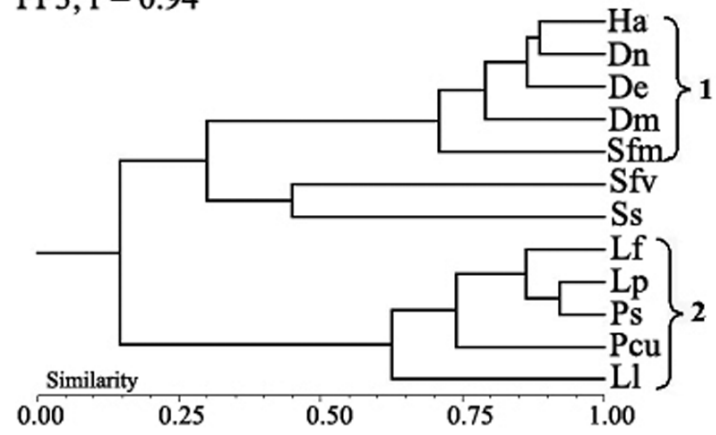

PP4; $r=0.93$
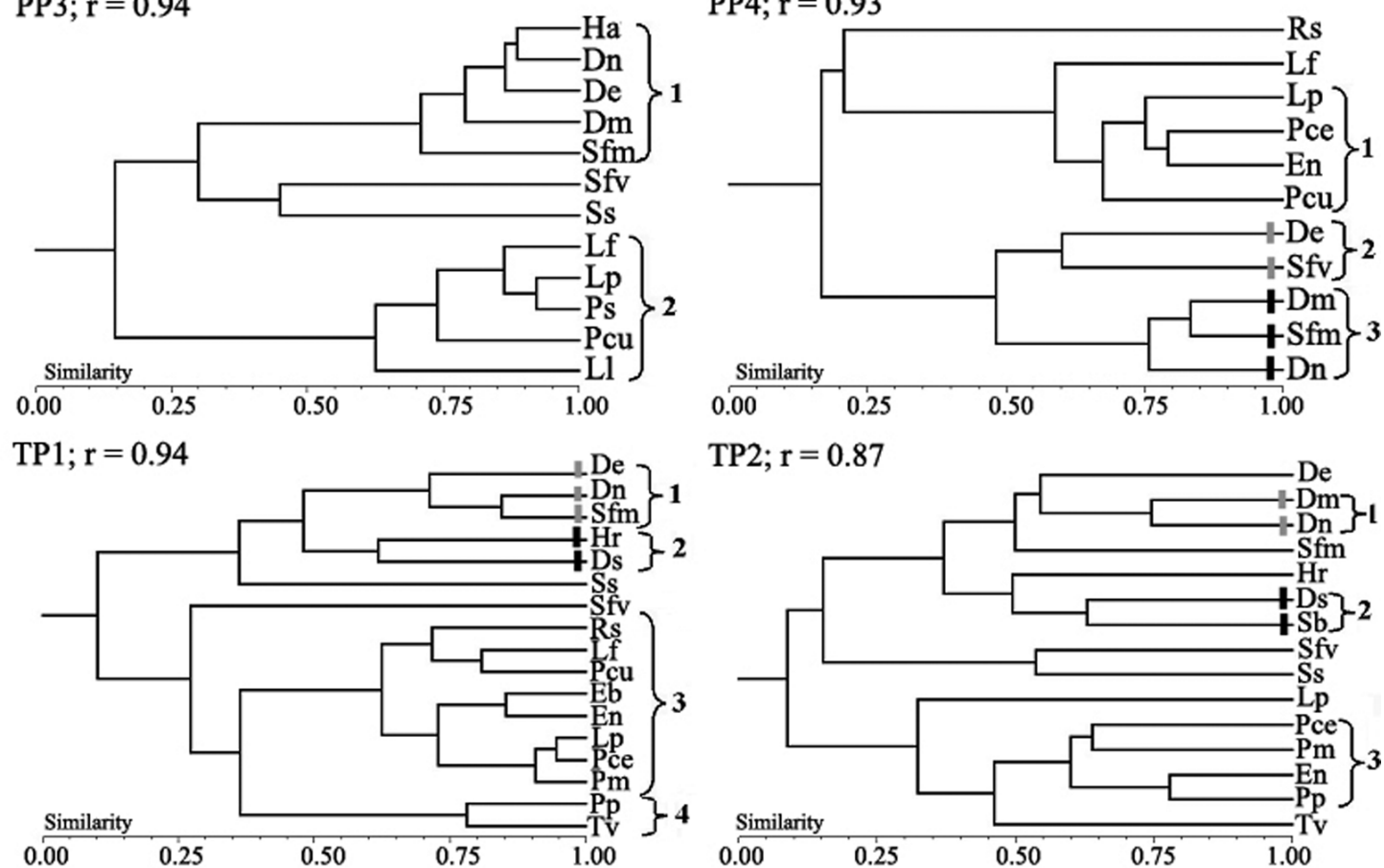

$\mathrm{TP} 2 ; \mathrm{r}=0.87$

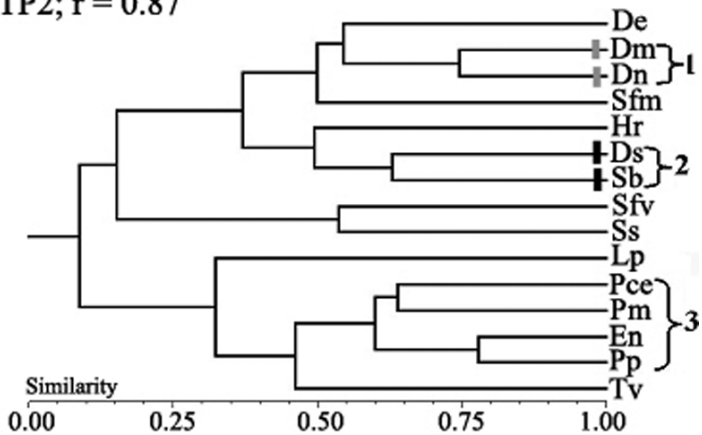

Figure 1 - Similarity of calling site use among males of species that called in permanent and temporary ponds in northwestern São Paulo State, Brazil. See Table 1 for explanation of abbreviations of names of water bodies. Numbers indicate the clusters with similarities higher than $60 \% . r=$ Coefficient of cophenetic correlation. Black bars represent species that called from lower perches, while gray bars indicates species that called from higher perches. Bufonidae (Rs, Rhinella schneideri); Hylidae (De, Dendropsophus elianeae; Dm, D. minutus; Dn, D. nanus; Ds, D. sanborni; Ha, Hypsiboas albopunctatus; Hr, H. raniceps; $\mathrm{Pp}$, Pseudis platensis; Tv, Trachicephalus venulosus; Sb, Scinax berthae; Sfm, S. fuscomarginatus; Sfv, S. fuscovarius; Ss, Scinax aff. similis); Leiuperidae (En, Eupemphix nattereri; Pce, Physalaemus centralis; Pcu, P. cuvieri; Pm, P. marmoratus; Ps, Pseudopaludicola aff. saltica); Leptodactylidae (Lf, Leptodactylus fuscus; L1, L. labyrinthicus; Lp, L. podicipinus); Microhylidae (Eb, Elachistocleis bicolor; Esp, Elachistocleis sp.). 

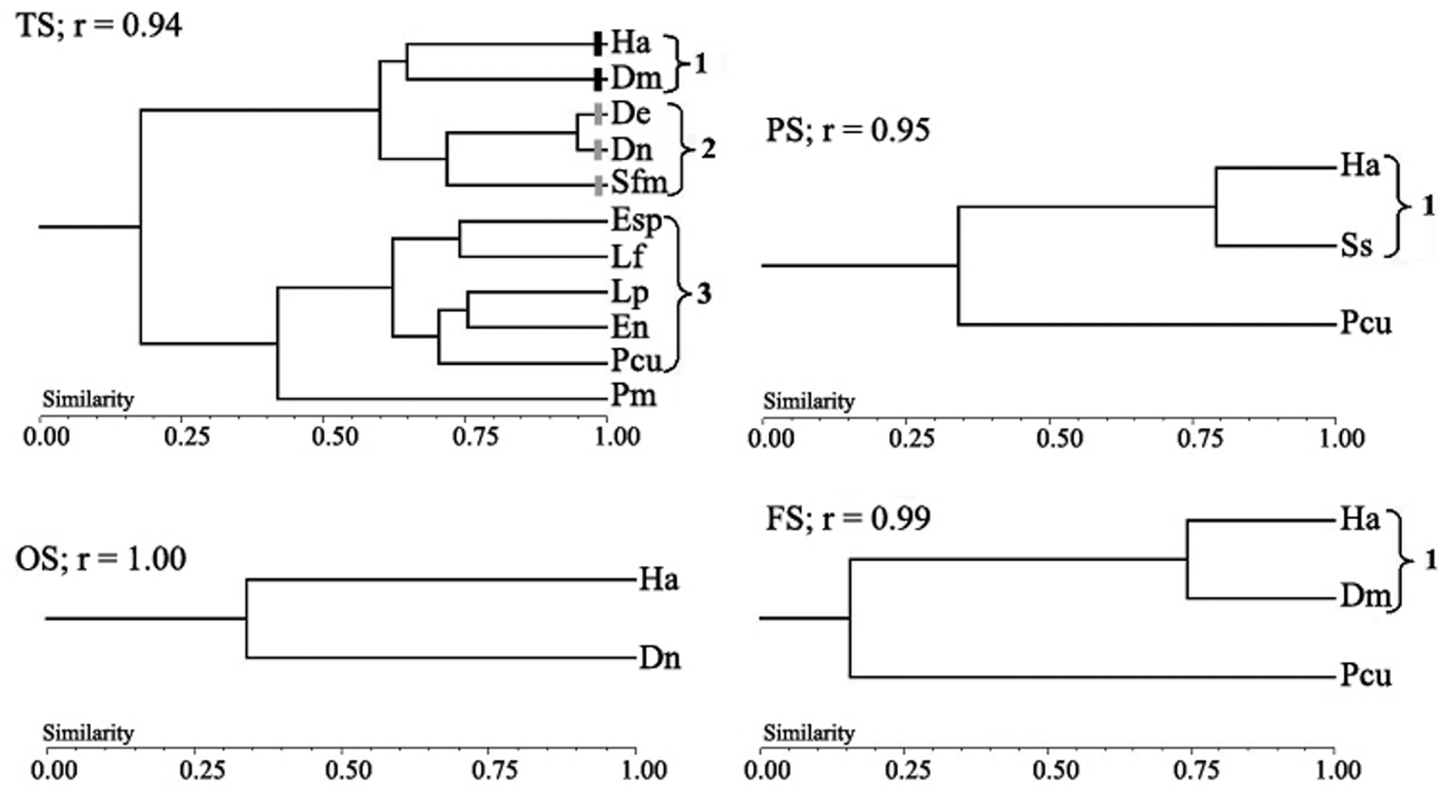

Figure 2. - Similarity of calling site use among males of species that called in swamps and streamlets in northwestern São Paulo State, Brazil. Numbers indicate the clusters with similarity higher than $60 \%$. Abbreviations of species follow those in Figure 1. See Table 1 for explanation of abbreviations of names of water bodies. Black bars represent species that called from lower perches, while gray bars indicates species that called from higher perches. $r=$ coefficient of cophenetic correlation.

different ponds (Table 2). Only males of Pseudopaludicola aff. saltica maintained the same depth and edge distance in different ponds (ANOVA, p > 0.05) (Table 2).

The advertisement call features analyzed did not reflect the phylogenetic relationship when considered the more inclusive level (family), but considering the genus level, the species of Hylidae reflected its phylogenetic relationship, except for Hypsiboas albopunctatus and $H$. raniceps (Figure 3 ). On the other hand, the congeneric species of Leptodactylidae and Leiuperidae segregated regarding the call features, whose advertisement calls were more different among themselves than were for Hylidae species (Figure 3). As shown in Figure 3 , clusters were basically constituted by Hylidae species (eight out of 12 Hylidae species), while one species of Leptodactylidae and Leiuperidae were clustered together with Hylidae species.

As shown in Figures 1 and 2 (similarities of calling sites) and Figure 3 (similarity of advertisement calls of studied species), it could be detected an inverse relationship between differential use of calling site and advertisement call features, since Hylidae species tend to use different calling sites and show higher similarities concerning advertisement calls features, and Leiuperidae/Leptodactylidae species tend to occupy similar calling sites but have more differentiated advertisement call.

\section{Discussion}

Most studies on calling sites of anurans are descriptive, employing different methods that 


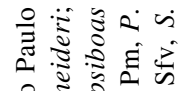

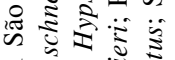

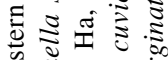

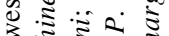

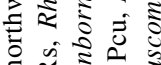

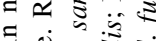
ज的的的

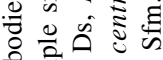
言芯芯 उ. ฮี

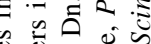

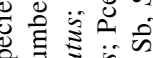
के

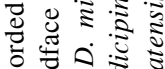
응 $\rightarrow$ है 2.

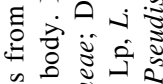
苛

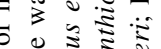

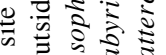
op 0 워

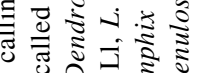

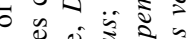
สิ

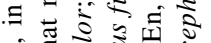

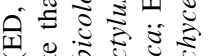

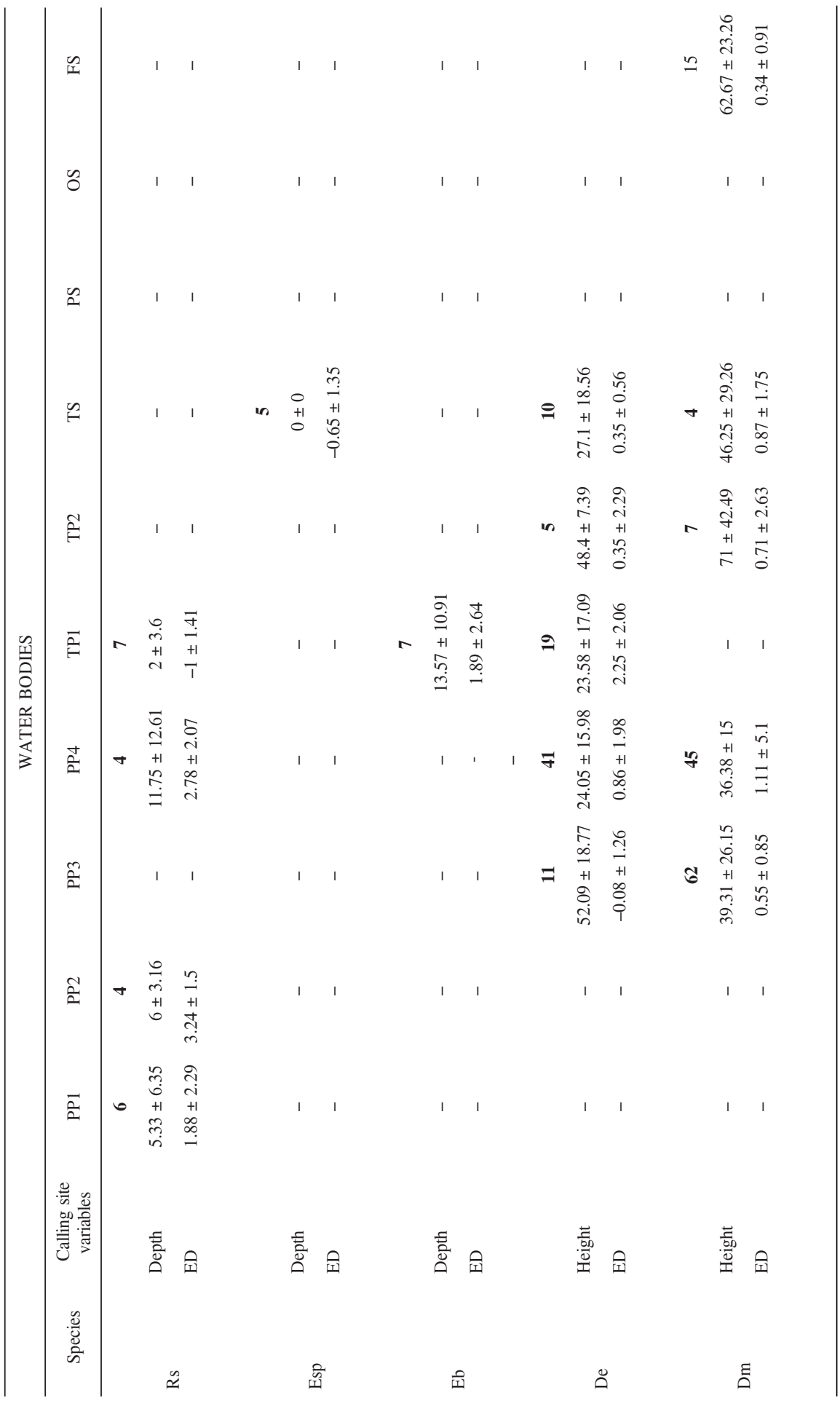
ช.

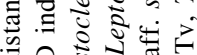

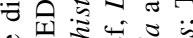

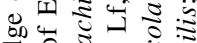
0.

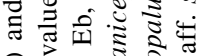

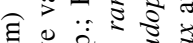
वे की

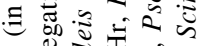

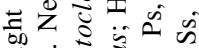

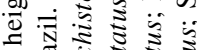

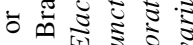
च. ज小

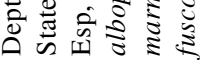
กั 


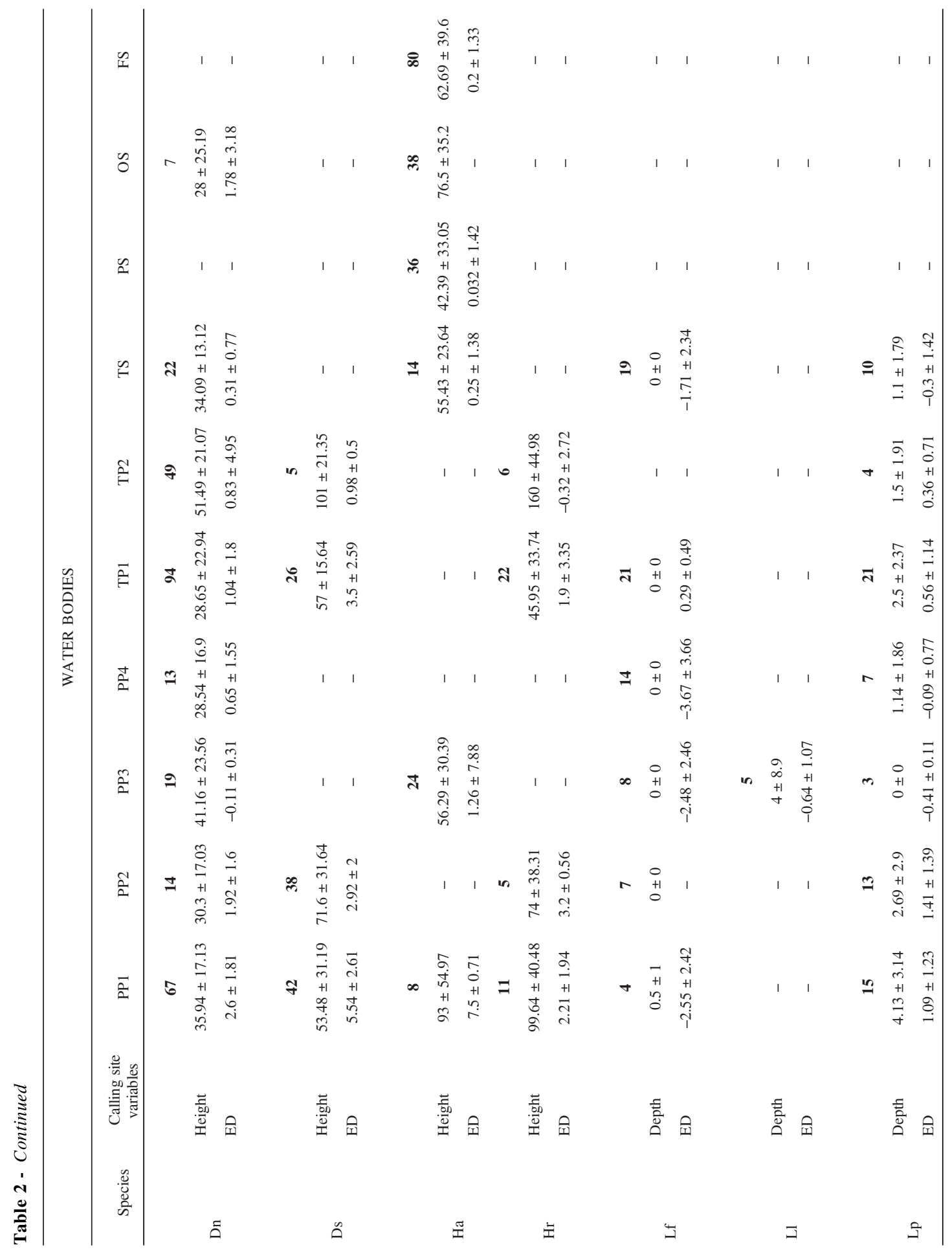




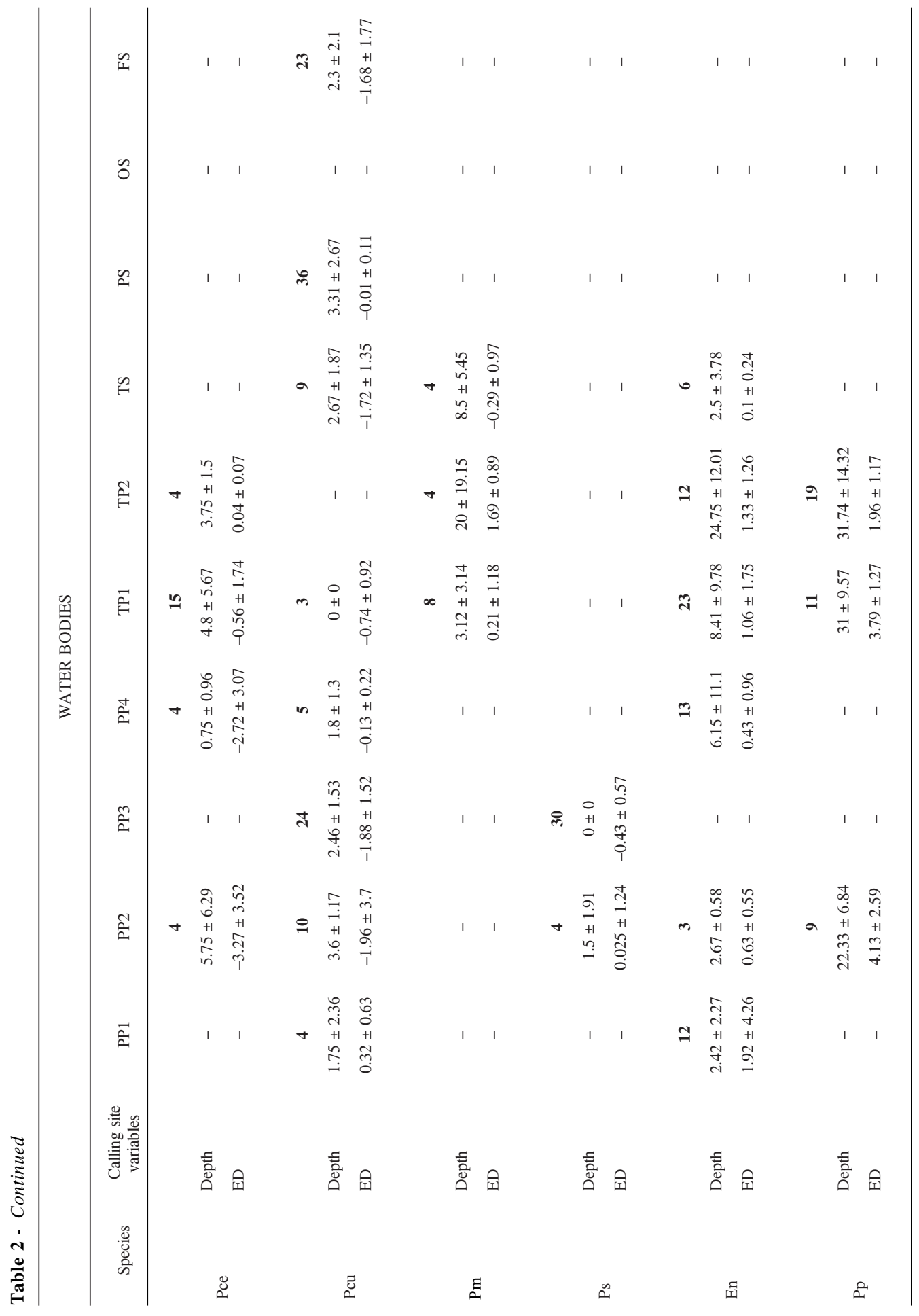




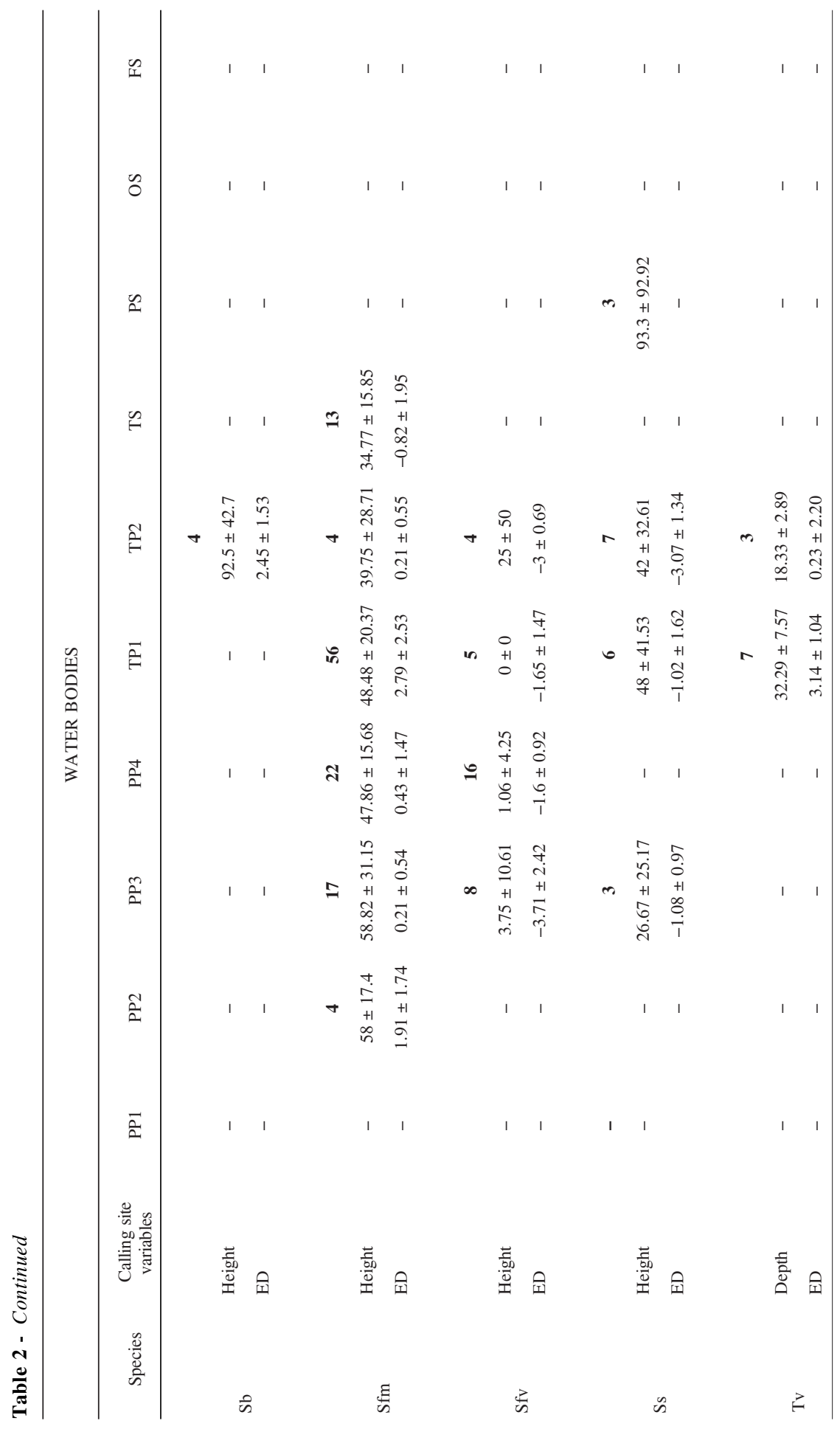


Table 3 - Percentage of overlap in calling site use and characterization of the four environmental descriptors at ten water bodies in the northwestern São Paulo State. Brazil. HEI, height of plants inside water bodies; VC, percentage of water surface covered by vegetation; SIZ, water body size; DUR, water body duration; N, number of species. Abbreviations for water bodies follow those in Table 1.

\begin{tabular}{|c|c|c|c|c|c|c|c|c|c|c|}
\hline \multirow[t]{2}{*}{$\begin{array}{l}\text { Water } \\
\text { bodies }\end{array}$} & \multirow[t]{2}{*}{$\begin{array}{c}\text { Species } \\
\text { richness }\end{array}$} & \multirow[t]{2}{*}{$\begin{array}{c}\% \text { species } \\
\text { with high } \\
\text { overlap }\end{array}$} & \multicolumn{4}{|c|}{$\begin{array}{l}\text { Environmental } \\
\text { heterogeneity }\end{array}$} & \multicolumn{2}{|c|}{$\begin{array}{l}\text { Perching } \\
\text { species }\end{array}$} & \multicolumn{2}{|c|}{ Terrestrial species } \\
\hline & & & HEI & $\mathrm{VC}$ & SIZ & DUR & & $\begin{array}{c}\text { Overlap } \\
(\%)\end{array}$ & & $\begin{array}{c}\text { Overlap } \\
(\%)\end{array}$ \\
\hline $\mathrm{TP} 1$ & 17 & 88.2 & 4 & 3 & 3 & 2 & 9 & 77.8 & 8 & 100 \\
\hline $\mathrm{TP} 2$ & 15 & 53.3 & 5 & 1 & 1 & 2 & 11 & 45.4 & 4 & 75 \\
\hline TS & 11 & 90.9 & 3 & 1 & 1 & 3 & 5 & 100 & 6 & 83.3 \\
\hline PP1 & 9 & 100 & 5 & 3 & 3 & 1 & 4 & 100 & 5 & 100 \\
\hline PP2 & 12 & 75 & 5 & 2 & 3 & 1 & 5 & 60 & 7 & 85.7 \\
\hline PP3 & 12 & 83.3 & 2 & 1 & 2 & 1 & 7 & 71.4 & 5 & 100 \\
\hline PP4 & 11 & 81.8 & 3 & 1 & 4 & 1 & 5 & 100 & 6 & 66.7 \\
\hline PS & 3 & 66.7 & 5 & 2 & 1 & 1 & 2 & 100 & 1 & 0 \\
\hline OS & 2 & 0 & 5 & 3 & 4 & 1 & 2 & 0 & 0 & - \\
\hline FS & 3 & 66.7 & 5 & 2 & 2 & 1 & 2 & 100 & 1 & 0 \\
\hline
\end{tabular}

make general comparisons difficult. However, it is possible to recognize two basic patterns of niche overlap in the calling sites of anurans. Among species calling in ponds located in open areas, there is high overlap (Pombal 1997, Bernarde and Anjos 1999, Rossa-Feres and Jim 2001, Pombal and Gordo 2004), due to the large number of species relative to the availability of calling sites (Cardoso et al. 1989). In contrast, species in ponds located in forested areas exhibit greater differential use of calling sites (Cardoso et al. 1989, Haddad and Sazima 1992, Bernarde and Anjos 1999, Bertoluci and Rodrigues 2002, Pombal and Gordo 2004), because of few species competing for relatively greater numbers of calling sites (Cardoso et al. 1989). However, some exceptions to the pattern of great overlap in open areas were reported by
Eterovick and Sazima (2000), Prado et al. (2005) and Santos and Rossa-Feres (2007). Santos and Rossa-Feres (2007) suggest that differential use of calling sites in open areas may be related to the unsaturation of the anuran assemblage, since partitioning is a consequence of low species richness in the pond.

Since vegetal heterogeneity provides major humidity, shelter and vocalization and oviposition sites (Parris and McCarthy 1999, Afonso and Eterovick 2007), it would be expected that environmental heterogeneity (at least vegetal descriptors, such as vegetation height and vegetal cover) would be correlated with degree of overlap of calling sites for both guilds analyzed. A major number of sampling ponds could change the statistical significance of the regression analysis, because according to 


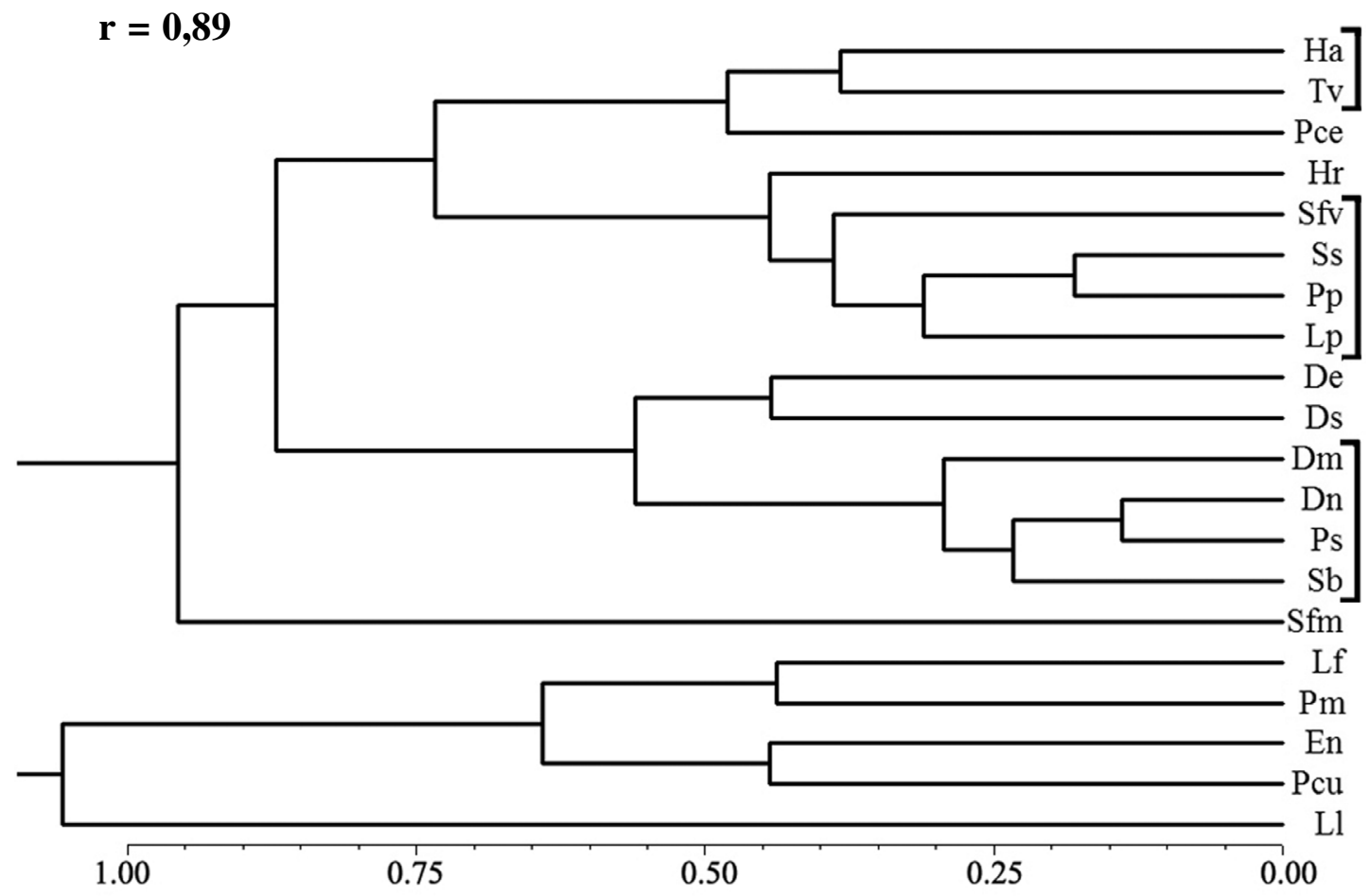

Figure 3 - Similarity on advertisement call of species recorded in northwestern São Paulo State, Brazil. $r=$ Coefficient of cophenetic correlation. Hylidae (De, Dendropsophus elianeae; Dm, D. minutus; Dn, D. nanus; Ds, D. sanborni; Ha, Hypsiboas albopunctatus; Hr, H. raniceps; Pp, Pseudis platensis; Tv, Trachycephalus venulosus; $\mathrm{Sb}$, Scinax berthae; Sfm, S. fuscomarginatus; Sfv, S. fuscovarius; Ss, Scinax aff. similis); Leiuperidae (En, Eupemphix nattereri; Pce, Physalaemus centralis; Pcu, P. cuvieri; Pm, P. marmoratus; Ps, Pseudopaludicola aff. saltica); Leptodactylidae (Lf, Leptodactylus fuscus; L1, L. labyrinthicus; Lp, L. podicipinus).

Zar (1999), the only way to reduce Type I error in statistical analysis (reject a null hypothesis when it is in fact true) is to increase the sampling number. On the other hand, overlap of calling sites recorded herein could be explained by the low environmental heterogeneity of water bodies, because there is a significant predominance of herbaceous vegetation in the edges of the ponds, as a consequence of agricultural impacts on edge vegetation. Thus, this high homogeneity of structural complexity of the studied ponds may have not been sufficient to enable calling site segregation among species. However, the tendency for differential use of calling sites among Hylidae species, evidenced by the formation of two clusters (higher and lower perching species) in five out of seven ponds with four or more species, could be explained due to differences in the use of a three-dimensional space (Cardoso et al. 1989).

In the current study, there is only one species (Pseudopaludicola aff. saltica) that established calling sites with the same depth and edge distance in different ponds, while calling sites of remainder species differed at least in one of these variables. Despite the lack of a correlation between the niche overlap among species in each water body and the 
environmental descriptors (vegetation height, vegetal cover percentage, size and hydroperiod), some species were apparently influenced by vegetation height. For example, males of Dendropsophus minutus and D. sanborni, perched on higher sites in ponds with higher plants (e.g. Temporary Pond 2). Menin et al. (2005) also found differences in height and type of substrate used for calling site by Dendropsophus nanus in three out of four ponds we studied (Permanent Pond 1, Temporary Pond 1, and Temporary Pond 2). The distribution of vegetation inside the water bodies also seems to have influenced the distance of calling sites from the pond's edge. Species that called in ponds with vegetation restricted to the edge tended to establish their calling sites near the edge (e.g. hylids at Permanent Pond 3 and Physalaemus marmoratus and Eupemphix nattereri at Temporary Swamp). In ponds where vegetation covered much of the water's surface, males of several species tended to call further from the edge (e.g. species that called at Temporary Pond 1). According to Cardoso et al. (1989), greater plasticity in calling site may be related to the low availability of microhabitats around the pond. In the current study, this low availability of microhabitat could be a consequence of the low environmental heterogeneity of the ponds. In addition, species living in unstable or disturbed environments, such as the studied site, tend to show broad niches (Heyer and Bellin 1973). Thus, the ability among the studied species to use multiple calling sites seems to be a trait that enables them to survive in these habitats, and that can also lead to high overlap of calling sites among species.

Niche complementarity occurs when niche differentiation among species involves several niche dimensions, and species that occupy a similar position along one dimension tend to differ along another dimension (Schoener 1968, Pianka 1981). For anurans, few studies in literature concerning niche complementarity are available, which generally verify the relationship among trophic and spatial niche (Duré and Kehr 2004, Menin et al. 2005). In the current study, the aquatic/terrestrial anurans (Bufonidae, Leiuperidae, Leptodactylidae, Microhylidae) exhibited high overlap in calling site but segregated the advertisement calls, while Hylidae species showed an inverse pattern: a higher similarity on advertisement call features and segregation in calling site. These data indicate a niche complementarity between physical (calling site use) and acoustic (advertisement call) space use for both guilds analyzed (aquatic/terrestrial and perching species), as reported previously by Santos and Rossa-Feres (2007) in another anuran assemblage in Southeastern Brazil. Thus, niche complementarity show a more actual picture of resource use by coexisting species, because high overlap along one resource dimension (e.g. calling sites) may be accommodated by separation along other resource dimension (e.g. advertisement call features), which explains the coexistence of several species in a same habitat (Pianka 1981, Putman 1994).

\section{Acknowledgements}

The authors are grateful to Arif Cais, Célio F. B. Haddad, Christopher Murphy, Cynthia P. A. Prado, Fernando B. Noll, Francisco Langeani Neto, Gustavo Q. Romero, Lilian Casatti, Ricardo Sawaya, Rogério Bastos, Tiago G. dos Santos, and two anonymous reviewers from FAPESP relative to the project of Scientific Initiation and Master's Degree of the first author. We are also grateful to UNESP and FUNDUNESP for the funding of English reviewing. This study was supported by Fundação de Amparo à Pesquisa do Estado de São Paulo (FAPESP: IC, 01/08675-0; MS, 02/ 11388-5; BIOTA/FAPESP, 01/13341-3). All sampling in this study has been conducted in compliance with applicable state and federal laws of Brazil (IBAMA license number 02001.007052/2001). 


\section{References}

Ab'Saber, A. N. 2003. Os Domínios de Natureza no Brasil: potencialidades paisagísticas. São Paulo. Ateliê Editorial. 159 pp.

Afonso, L. G. and P. C. Eterovick. 2007. Spatial and temporal distribution of breeding anurans in streams in southeastern Brazil. Journal of Natural History 41: 949-963.

Aichinger, M. 1987. Annual activity patterns of anurans in a seasonal neotropical environment. Oecologia 71: 583-592.

Ayres, M., M. Ayres Jr., D. L. Ayres, and A. S. Santos. 2003. BioEstat 3.0. Aplicações estatísticas nas áreas das ciências biológicas e médicas. Belém. Sociedade Civil de Mamirauá. 291 pp.

Barcha, S. F. and F. M. Arid. 1971. Estudo da evapotranspiração na região norte-ocidental do Estado de São Paulo. Revista de Ciências da Faculdade de Ciências e Letras 1: 94-122.

Bernarde, P. S. and L. Anjos. 1999. Distribuição espacial e temporal da anurofauna no Parque Estadual Mata dos Godoy, Londrina, Paraná, Brasil (Amphibia, Anura). Comunicações do Museu Ciências e Tecnologia da PUCRS, Série Zoologia 12: 111-140.

Bertoluci, J. and M. T. Rodrigues. 2002. Utilização de habitats reprodutivos e micro-hábitats de vocalização em uma taxocenose de anuros (Amphibia) da Mata Atlântica do Sudeste do Brasil. Papéis Avulsos de Zoologia, São Paulo 42: 287-297.

Candeira, C. P. 2007. Estrutura de Comunidades $e$ Influência da Heterogeneidade Ambiental na Diversidade de Anuros em Área de Pastagem no Sudeste do Brasil. Unpublished M. Sc. Dissertation. Universidade Estadual Paulista, São José do Rio Preto, Brazil.

Cardoso, A. J., G. V. Andrade and C. F. B. Haddad. 1989. Distribuição espacial em comunidades de anfíbios (Anura) no sudeste do Brasil. Revista Brasileira de Biologia 49: 241-249.

Conte, C. E. and R. A. Machado. 2005. Riqueza de espécies e distribuição espacial em comunidade de anuros (Amphibia, Anura) em uma localidade de Tijucas do Sul, Paraná, Brasil. Revista Brasileira de Zoologia 22: 940-948.

Duellman, W. E. 1997. Amphibians of La Escalera Region, Southeastern Venezuela: Taxonomy, Ecology, and Biogeography. Scientific Papers, Natural History Museum, The University of Kansas 2: 1-52.

Duellman, W. E. and R. A. Pyles. 1983. Acoustic resource partitioning in anuran communities. Copeia 1983: 639 649.

Duellman, W. E. and L. Trueb. 1994. Biology of Amphibians. Baltimore and London. McGraw-Hill. 670 pp.
Duré, M. I. and A. I. Kehr. Influence of microhabitat on the trophic ecology of two leptodactylids from northeastern Argentina. Herpetologica 60: 295-303.

Eterovick, P. C. and I. Sazima. 2000. Structure of an anuran community in a montane meadow in southeastern Brazil: effects of seasonality, habitat, and predation. Amphibia-Reptilia 21: 439-461.

Fraser, R. H. 1998. Vertebrate species richness at the mesoscale: relative roles of energy and heterogeneity. Global Ecology and Biogeography Letters 7: 215-220.

Haddad, C.F.B. 1998. Biodiversidade dos anfíbios no Estado de São Paulo. Pp. 15-26 in R. M. C. Castro (ed.), Biodiversidade do Estado de São Paulo, Brasil (Série Vertebrados). São Paulo. FAPESP.

Haddad, C. F. B. and C. P. A. Prado. 2005. Reproductive modes in frogs and their unexpected diversity in the Atlantic Forest of Brazil. BioScience 55: 207-217.

Haddad, C. F. B. and I. Sazima. 1992. Anfíbios anuros da Serra do Japi. Pp. 188-211 in L. P. C. Morellato (ed.), História Natural da Serra do Japi: Ecologia e Preservação de uma Área Florestal no Sudeste do Brasil. Campinas e São Paulo. Edunicamp/FAPESP.

Heyer, W. R. and M. S. Bellin. 1973. Ecological notes on five sympatric Leptodactylus (Amphibia, Leptodactylidae) from Ecuador. Herpetologica 29: 66-72.

Heyer, W. R., A. S. Rand, C. A. G. Cruz, O. L. Peixoto, and C. E. Nelson. 1990. Frogs of Boracéia. Arquivos de Zoologia, São Paulo 31: 231-410.

Hödl, W. 1977. Call differences and calling sites segregation in anuran species from Central Amazonian floating meadows. Oecologia 28: 351-363.

Hofer, U., L. F. Bersier and D. Bocard. 2004. Relating niche and spatial overlap at the community level. Oikos 106: 366-376.

Krebs, C. J. 1999. Ecological Methodology. Menlo Park. Addison Wesley Educational Publishers. 620 pp.

Martins, I. A. and J. Jim. 2003. Bioacoustic analysis of advertisement call in Hyla nana and Hyla sanborni (Anura, Hylidae) in Botucatu, São Paulo, Brazil. Brazilian Journal of Biology 63: 507-516.

Martins, I. A., S. C. Almeida and J. Jim. 2006. Calling sites and acoustic partitioning in species of the Hyla nana and rubicundula groups (Anura, Hylidae). Herpetological Journal 16: 239-247.

Menin, M., D. C. Rossa-Feres and A. A. Giaretta. 2005. Resource use and coexistence of two syntopic hylid frogs (Anura, Hylidae). Revista Brasileira de Zoologia 22: 61-72.

Moreno-Rueda, G. and M. Pizarro. 2007. The relative influence of climate, environmental heterogeneity, and 
human population on the distribution of vertebrate species richness in south-eastern Spain. Acta Oecologica 32: 50-58.

Parris, K. M. and M. A. McCarthy. 1999. What influences the structure of frog assemblages at forest streams? Australian Journal of Ecology 24: 495-502.

Pianka, E. R. 1981. Competition and niche theory. Pp. 167196 in R.M. May (ed.), Theoretical Ecology - principles and applications. Oxford. Blackwell Scientific Publications.

Pombal, J. P. Jr. 1997. Distribuição espacial e temporal de anuros (Amphibia) em uma poça permanente na Serra de Paranapiacaba, sudeste do Brasil. Revista Brasileira de Biologia 57: 583-594.

Pombal, J. P. Jr. and M. Gordo. 2004. Anfíbios anuros da Juréia. Pp. 243-256 in O. A. V. Marques and W. Duleba (eds.), Estação Ecológica Juréia-Itatins ambiente físico, flora e fauna. Ribeirão Preto. Holos Editora.

Prado, C. P. A., M. Uetanabaro and C. F. B. Hadad. 2005. Breeding activity patterns, reproductive modes, and habitat use by anurans (Amphibia) in a seasonal environment in the Pantanal, Brazil. Amphibia-Reptilia 26: $211-221$.

Putmann, R. J. 1994. Community Ecology. London. Chapman \& Hall. 178 pp.

Rohlf, F. L. 2000. NTSYS 2.1: Numerical taxonomy and multivariate analysis system. New York. Exeter Software.

Romesburg, H. C. 1984. Cluster Analysis for Researchers. Malabar. Robert E. Krieger Publishing Company. 334 pp.
Rossa-Feres, D. C. and J. Jim. 2001. Similaridade no sítio de vocalização em uma comunidade de anfíbios anuros na região noroeste do Estado de São Paulo, Brasil. Revista Brasileira de Zoologia 18: 439-454.

Santos, T. G. and D. C. Rossa-Feres. 2007. Similarities in calling site and advertisement call among anuran amphibians in southeastern Brazil. South American Journal of Herpetology 2: 17-30.

Santos, T. G., D. C. Rossa-Feres and L. Casatti. 2007. Diversidade e distribuição espaço-temporal de anuros em região com pronunciada estação seca no sudeste do Brasil. Iheringia, Série Zoologia 97: 37-49.

São Paulo. 2000. Atlas das Unidades de Conservação Ambiental do Estado de São Paulo. São Paulo. Secretaria do Meio Ambiente. 64 pp.

Schoener, T. W. 1968. The Anolis lizards of Bimini: resource partitioning in a complex fauna. Ecology 49 : 704-726.

Triola, M. F. 1999. Introdução à Estatística. Rio de Janeiro. Livros Técnicos e Científicos Editora S. A. $410 \mathrm{pp}$.

Vasconcelos, T. S. and D. C. Rossa-Feres. 2005. Diversidade, distribuição espacial e temporal de anfíbios anuros (Amphibia, Anura) na região noroeste do estado de São Paulo, Brasil. Biota Neotropica 5(2): 137-150. Available from: http://www.scielo.br/scielo.php? s c ri p t $=$ s c i a r t e x t \& pi d = S 1676 . 06032005000300010\&lng=en.

Zar, J. H. 1999. Biostatistical Analysis. New Jersey. Prentice Hall. 663 pp. 